\title{
CHEMICAL AND PHYSICAL PROPERTIES OF LIMESTONE POWDER AS A POTENTIAL MICROFILLER OF POLYMER COMPOSITES
}

\author{
M. KĘPNIAK ${ }^{1}$, P. WOYCIECHOWSKI ${ }^{2}$, W. FRANUS ${ }^{3}$
}

\begin{abstract}
The preliminary stage of asphalt mixture production involves the drying and dedusting of coarse aggregates. The most common types of coarse aggregates used are limestone and basalt. In the process of drying and dedusting the dryer filter accumulates large quantities of waste in the form of mineral powder.

This paper introduces an investigation into limestone powder waste as a potential microfiller of polymer composites. Physical characteristics such as the granulation the of powder collected from the filter - in terms of the season of its collection and the type of input materials used - were analysed. A scanning electron microscope (SEM) was used for the investigation described within this paper. The obtained results were compared against those of other materials which can be used as polymer composites microfillers.
\end{abstract}

Keywords: limestone powder waste, polymer composites, microfiller, grain size analysis

\section{INTRODUCTION}

The importance of sustainability in building development is an issue that is constantly amassing interest. Significant emphasis is placed on treating natural resources as a limited element as well as on implementing rational waste management. The gradually increasing amount of waste collected

\footnotetext{
${ }^{1}$ M.Sc., Eng., Warsaw University of Technology, Faculty of Civil Engineering, Al. Armii Ludowej 16, 00-637 Warsaw, Poland, e-mail: m.kepniak@il.pw.edu.pl

${ }^{2} \mathrm{PhD}$., DSc., Warsaw University of Technology, Faculty of Civil Engineering, Al. Armii Ludowej 16, 00-637 Warsaw, Poland, e-mail: p.woyciechowski@il.pw.edu.pl

${ }^{3}$ PhD., DSc., Lublin University of Technology, Faculty of Civil Engineering, Nadbystrzycka 40, 20-618 Lublin , Poland, e-mail: w.franus@pollub.pl
} 
requires us to constantly consider new ways of disposal and repurposing. Modern material science, including construction material engineering, allows for significant modifications of the resulting composites and, as a result, new directions of research on building materials, including waste management issues. Attempts at these strategies and continuous efforts to lower production costs make for an increasingly wider interest in the field of waste material use; as substitution for traditionally used raw materials from non-renewable sources, for example. Among others, limestone powder obtained as a by-product of asphalt mix (MMA) production can be viewed as a valuable component of different composite materials. This by-product is partially used by MMA producers as a mix microfiller [1]. An excessive amount of this powder is readily, as it is considered as a waste product. Some attempts to use waste powders as additives or microfillers in cement/concrete production are presented in literature [2,3]. As far as the authors of this paper know, there is no publications regarding the use of this type of by-product as a microfiller in polymer composites; however, the use of specially produced limestone powder in these types of composites is known from previous research [4]. The aim of this paper is to discuss the potential of using this by-product as a microfiller in the polymer concrete industry.

\section{WASTE POWDER CHARACTERISTICS -RESULTS AND DISCUSSION}

The preliminary stage in the production of asphalt mixtures (MMA) is the drying and dedusting of coarse aggregates. The most common types of coarse aggregates in MMA are limestone and basalt, due to the fact that these two are alkaline, and therefore have good adhesion with asphalt. During the process of drying and dust extraction, the dryer filter accumulates large quantities (approximately $5-10 \%$ of the aggregate mass) of waste in the form of mineral powder $[2,3]$. Nowadays, the technology of MMA production allows for the recycling of a small part of the mineral powder waste. However, in most cases it is used as a filler in excavations or in embankment construction. Smaller production plants are forced to pay for the removal and disposal of the powder.

\subsection{Physical Properties}

The physical characteristics of waste powder depend on the properties of the material from which they it is recovered. (Tab. 1). The granulation of the powder originating from the filter depends not 
only on the type of raw materials input, but also on the season in which they were collected. In winter, for example, aggregates stored in heaps are characterised by higher humidity and lower temperature, as compared to those of summer months. Higher humidity in aggregates causes the larger particles of dirt to adhere to its surface. This phenomenon can be explained by the correlation of an increase in adhesion between particles with an increase in humidity. In addition, changes of temperature and humidity cause some modifications in the process of drying and extraction. The following parameters can be modified: duration, temperature, and the air flow power of the dryer. These modifications as well as the initial particle size of aggregate pollution cause the powder, which is collected into the filters, to show significant variation in one year-long cycle.

Table 1. Physical characteristics of the tested limestone powder waste.

\begin{tabular}{|c|c|c|}
\hline No. & Property & Value \\
\hline 1 & Colour & light grey - dark grey \\
\hline 2 & $\mathrm{pH}$ (of water slurry) & $11 \div 13$ \\
\hline 3 & Specific Density, $\mathrm{g} / \mathrm{cm}^{3}$ & $2.65 \div 3.00$ \\
\hline 4 & Bulk Density (in loose state), $\mathrm{g} / \mathrm{cm}^{3}$ & $0.7 \div 1.1$ \\
\hline 5 & Chlorides content, $\%$ & $0.004 \div 0.034$ \\
\hline
\end{tabular}

Initial analyses carried out in MMA factories showed that in the winter period the waste has a higher proportion of coarse grain as compared to summer period; which could potentially have a significant impact on the characteristics of the modified concrete. Figure 1 describes the verification of grain size distribution depending on the month in which the samples were collected (Fig. 1). The samples selected for the analysis were collected during the production process of a mixture of one single composition, they were, however, from different months.

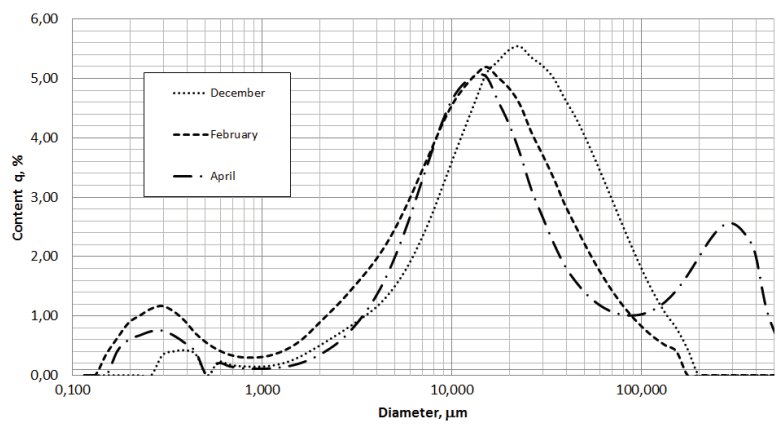

Fig. 1. Verification of grain size distribution depending on the month in which the samples were collected 
The specific area and relative frequency of powder grain size distribution were tested via the Laser Diffraction Particle Size Analyzer, Horriba LA-300 and the Laser Scattering Method (LSM) was used. Sodium polimetaphosphate (NaPO3)x was used as a dispersing agent. The concentration of the solution was $0.2 \%$. Ultrasound waves were used to break up the potential agglomerates of the particles, cycle duration was 1 minute. Circulation pump speed while measuring was 7.0.

Table 2 illustrates the mixture proportions of the raw materials input. The curves characterizing the verification of grain size distribution (depending on which raw material is input) are presented in Fig. 2. We see that similar raw material mineral input provides similar granulation, independent of mass fraction. Significant differences can be achieved through changes in the type of mineral composition.

Table 2. Raw material input mixture proportions

\begin{tabular}{|c|c|c|c|c|}
\hline \multirow{2}{*}{ Type of aggregate } & \multicolumn{4}{|c|}{ Mixture no. } \\
\cline { 2 - 5 } & 1 & 2 & 3 & 4 \\
\hline melaphir aggregate $2 / 5$ & - & - & $20 \%$ & $17 \%$ \\
\hline melaphir aggregate 4/8 & - & - & $30 \%$ & $83 \%$ \\
\hline melaphir aggregate 8/11 & - & - & $20 \%$ & - \\
\hline amphibolite aggregate 6/11 & - & $21 \%$ & - & - \\
\hline limestone aggregate $2 / 8$ & $34 \%$ & $29 \%$ & - & - \\
\hline limestone aggregate 8/16 & $33 \%$ & $29 \%$ & - & - \\
\hline limestone aggregate16/22 & $33 \%$ & $13 \%$ & - & - \\
\hline serpentinite aggregate $0 / 5$ & - & $9 \%$ & $31 \%$ & - \\
\hline
\end{tabular}

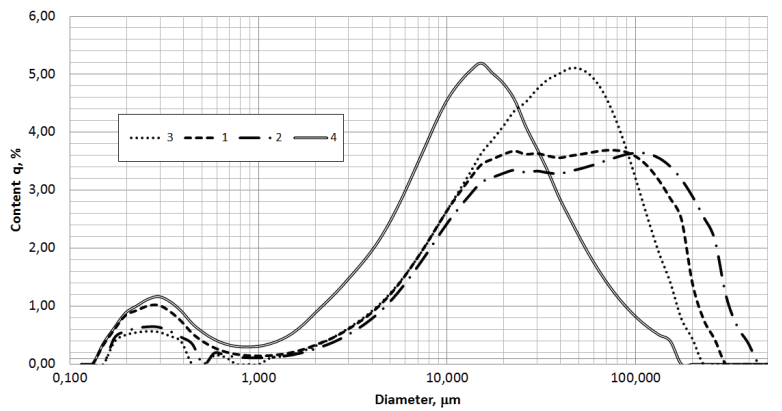

Fig. 2. Verification of grain size distribution curves vs. mineral input composition. 1,2,3,4-mixture number

Microfillers for polymer concretes and polymer composites have to be very fine, usually containing grains up to $120 \mu \mathrm{m}$ in size, and have to be petrographically comparable to basic aggregates [5][6]. For this reason, the most commonly used microfiller is quartz powder. The situation of the construction materials market shows that the quantity of this material is limited and therefore its 
costs can be quite high. Examples of successful substitutions with waste microfillers are: fluidized fly ash [7,8], water sediments [9], perlite powder [10,11], palm oil fuel ash [12], and glass powder [13].

The results obtained for the limestone powder waste mix were compared with analogical data received for other mineral powders used as microfillers of polymer concretes and composites.

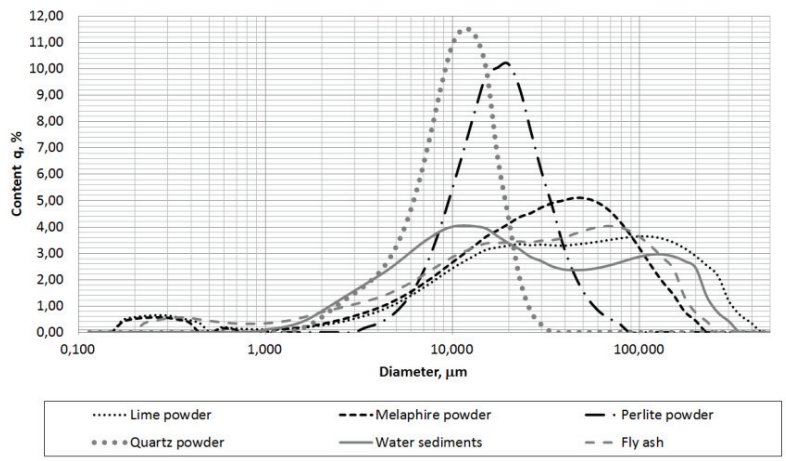

Fig. 3. Verification of grain size distribution curves of tested microfillers - relative frequency plot

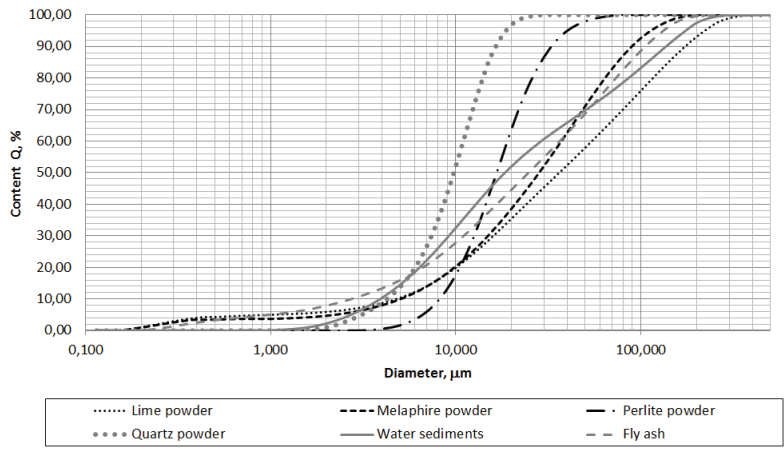

Fig. 4. Verification of grain size distribution curves of tested microfillers - cumulative frequency plot

It's apparent that in spite of the fact that the grain size distribution of the tested waste powder differs from that of quartz powder, the mode values of their diameters remained similar. Limestone powder waste grain distribution is similar to that of the generally obtained quartz microfiller, however it contains a significantly higher amount of large grains (around 50-100 $\mu \mathrm{m}$ in diameter). Nevertheless, it is worth noting that the powder fulfills the requirements for microfillers $(98 \%$ of grain size less than $120 \mu \mathrm{m}$ in diameter). From a technical point of view, the value of the specific 
surface area as high as $26000 \mathrm{~cm}^{2} / \mathrm{cm}^{3}$ can result in a lower workability of fresh mixtures. However, the values presented in Table 3 are not sufficient enough to confirm this assumption, as they were obtained from the Laser Diffraction Particle Size Analyzer, which assumes that the shape of the grains is always spherical. Sometimes even lower values of this characteristic can be confusing as, for example, perlite powder, which is characterised by a branched and ragged shape, which can cause significant reduction in workability [9].

Table 3. Specific surface area, average diameter, mode diameter, and content percentage under $120 \mu \mathrm{m}$ of tested microfillers.

\begin{tabular}{|c|c|c|c|c|}
\hline Microfiller & $\begin{array}{c}\text { Specific surface area, } \\
\mathrm{cm}^{2} / \mathrm{cm}^{3}\end{array}$ & $\begin{array}{c}\text { Average diameter, } \\
\mu \mathrm{m}\end{array}$ & Mode diameter, $\mu \mathrm{m}$ & $\begin{array}{c}\text { Content under } \\
120 \mu \mathrm{m}, \%\end{array}$ \\
\hline lime powder & 26444 & 27.47 & 14.19 & 98.16 \\
\hline melaphire powder & 25174 & 11.73 & 14.10 & 100.00 \\
\hline quartz powder & 7847 & 10.19 & 10.83 & 100.00 \\
\hline perlite powder & 4392 & 18.83 & 18.49 & 100.00 \\
\hline water sediments & 6046 & 46.25 & 10.81 & 86.48 \\
\hline fly ash & 9718 & 35.16 & 41.92 & 98.13 \\
\hline
\end{tabular}

\subsection{CHEMiCAL AND MineralogicAl CHARACTERISTICS}

Mineral composition of limestone is presented in Figure 5A. XRD analysis shows that the main mineral component is calcite $(\mathrm{C})$ recognized by the main $\mathrm{d}_{\mathrm{hkl}}$ spacing $3.86 ; 3.03 ; 2.84 ; 2.49 ; 2.28$; $1.91 \AA$. Its quantity is about $85 \%$ of the total compound. In small quantities, the minerals from a group of carbonates and are represented by dolomite (D) recognized by $d_{h k l} 2.89 ; 2.45$. The mineral composition is complemented by quartz (Q) recognized by dhkl $4.26 ; 3.34 ; 2.28 \AA$, feldspar $\mathrm{d}_{\mathrm{hkl}}$ $3.25 ; 3.19 \AA$ and Clay minerals represented by trace amounts of illite and kaolinite. Petrographically, the sample is classified as limestone powder.

Figure $5 \mathrm{~B}$ presents the chemical composition of limestone powder. The main component is $\mathrm{CaO}$ which, when calculated down to content as $\mathrm{CaCO}_{3}$, is $84.85 \%$ wt. $\mathrm{SiO}_{2}$ is $7.06 \%$ wt., $\mathrm{Al}_{2} \mathrm{O}_{3} 2.38$ $\% w t$, and their carriers are aluminosilicates occurring in the form of feldspars and clay minerals, as well as quartz.

Chemical and mineralogical analysis of the tested waste powder shows that it is similar to the limestone powder used successfully in polymer composites. It should be noted that percentages as high as $10 \%$ (components other than limestone and silica) could influence microfiller-resin compatibility. 


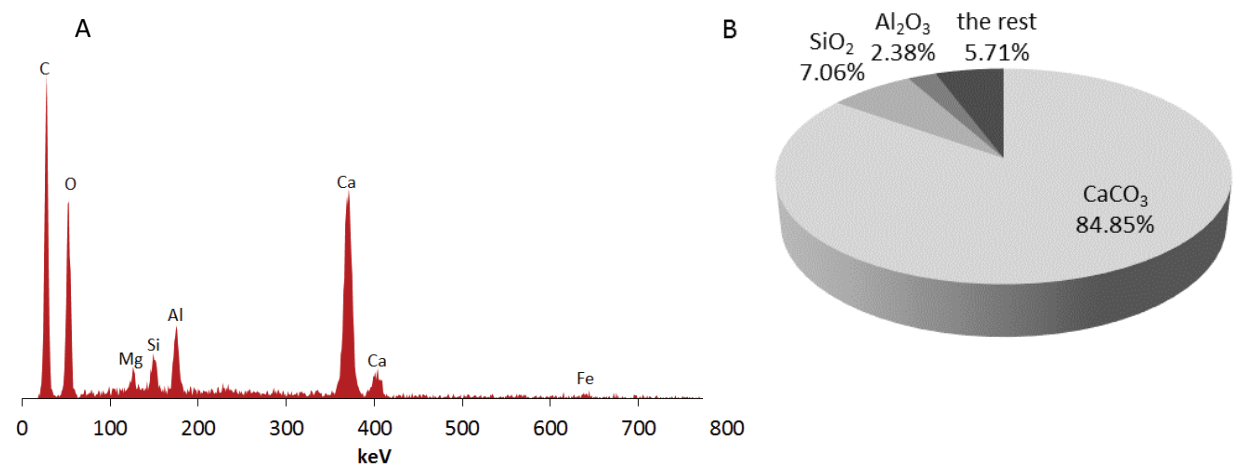

Fig. 5. The mineral (A) and chemical (B) composition of the tested limestone powder.

\subsection{MICROSCOPIC OBSERVATIONS}

Scanning electron microscopy (SEM) was used for the presented investigation.

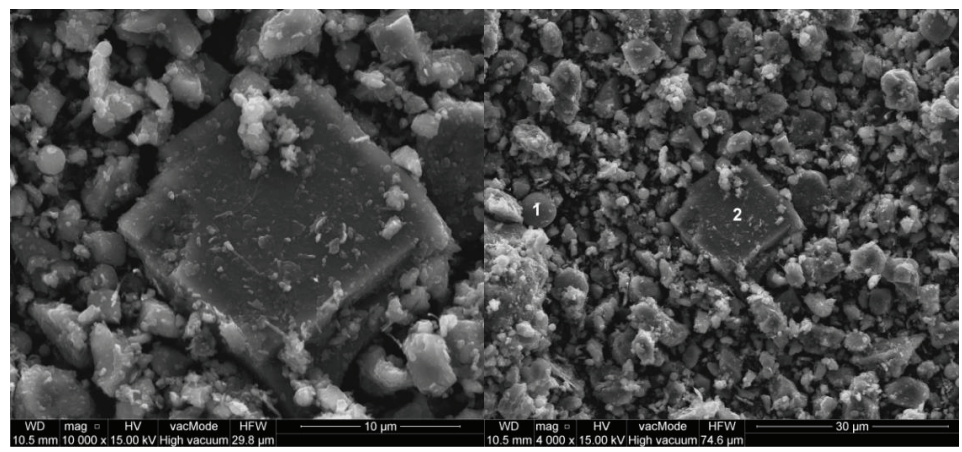

Fig. 6. Microscopic photograph of waste limestone powder grain shape, 1-aluminium silicate grain 2-limestone grain.

Grain shapes seen here are similar to grain shape of coarse aggregates. Grains of limestone powder have smooth edges, which results in a reduction of specific surface area. This can be beneficial in terms of the required resin volume ratio, which is necessary for bond performance. Compared to quartz powder, the grain shape of limestone powder is less effective. However, comparing to other waste microfillers (for example the branched and ragged shape of perlite powder) limestone powder has a more advantageous grain shape.

In Figure 7 the spherical particle marked by the number 2 is an aluminum silicate grain. Figure 8 shows its chemical composition. The presence of aluminum silicate grains most probably can be 
explained through the burning process inside the dryer, where temperature can exceed $800^{\circ} \mathrm{C}$ (this temperature is similar to that of the fluidizing burning of coal).

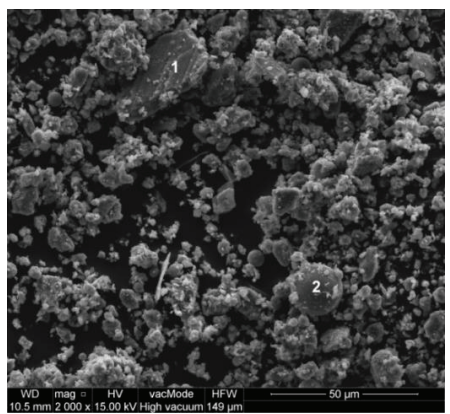

Fig. 7. Microscopic picture of limestone powder waste: 1 - limestone grain , 2- aluminium silicate grain

1)

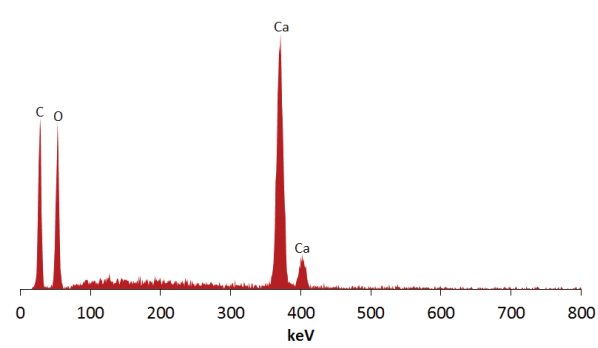

2)

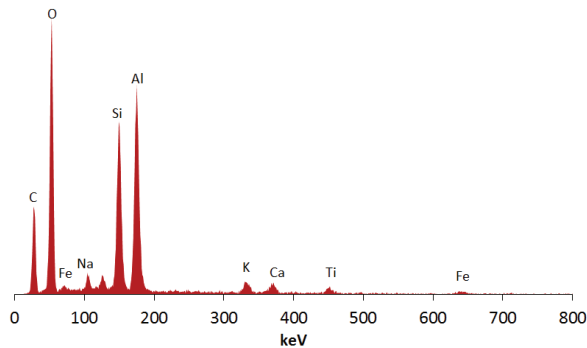

Fig. 8.The chemical composition of selected grains: 1 - limestone grain , 2- aluminium silicate grain

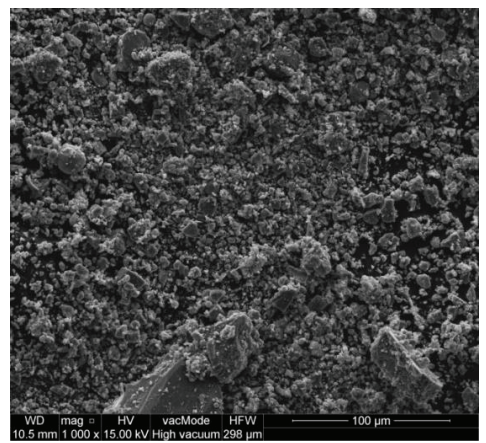

Fig. 9. Microscopic photograph of limestone powder waste - spatial grain arrangement 
In Figure 9, it is observed that the volume fraction of the larger particles is relatively low in quantity. Particles with a grain size of around $10 \mu \mathrm{m}$ in diameter dominate the composition.

Shape analysis confirms that the tested limestone powder does not differ significantly from typical polymer composites microfillers.

\section{CONCLUSION}

All the results obtained through our research confirm that the possibility of use of limestone powder waste in polymer composites is definitely worth the, even as a partial substitution of quartz powder. When evaluating one specific type of mineral as the basis for raw material input, the grain size distribution of the waste powders remained similar. The differences connected with seasonal changes are noticeable, though not statistically significant for our purposes. Grain size distribution curves of limestone powder waste and mode diameters are similar to those of quartz powder, however limestone powder contains a higher amount of larger particles. The shape of the grains is promising from the practical technical point of view. In terms of workability, consistency, and low resin usage, unbranched smooth grains are advantageous.

However, the chemical composition of the powder indicates the need for further analysis of the resin-limestone powder waste compatibility. Most of the microfillers used in polymer composites are siliceous, so the compatibility with limestone powder waste is not a well-examined factor. To verify this compatibility, field tests of the workability, strength, and durability of modified composites should be performed. The reason for this planned investigation is the fact that such a modification could be proven beneficial, both economically (reduction of material costs) and ecologically (use of waste material). 


\section{REFERENCES}

1. M. Karasahin, S. Terzi, „Evaluation of marble waste dust in the mixture of asphaltic concrete”, Construcition and Building Materials, 21,616-620, 2007

2. M. Dobiszewska, J. Kuziak, P. Woyciechowski, M. Kępniak, „ Główne aspekty trwałości betonu modyfikowanego odpadowym pyłem bazaltowym z odpylania kruszyw w wytwórni MMA”, Journal of Civil Engineering, Environment and Architecture, 1/I/2016, 115-122, Rzeszów, 2016

3. M. Dobiszewska, W. Franus, S. Turbiak, , Analiza możliwości zastosowania odpadowego pyłu bazaltowego w zaprawie cementowej", Journal of Civil Engineering, Environment and Architecture, 1/I/2016, 107-114, Rzeszów, 2016

4. A. Abina, U. Puc, A. Jeglic, J. Prah, R. Venckevicius, I. Kasalynas, G. Valusis, A. Zidansek "Qualitative and quantitative analysis of calcium-based microfillers using terahertz spectroscopy and imaging", Telanta 143, $169-177,2015$

5. L. Czarnecki, A. Garbacz, K. Kurzydłowski, "Morfology of polimer concreto microstructure", Proc. of the 8th Int. Congress on Polymers on Concrete ICPIC'95, Oostende , 299-304,1995

6. A. Garbacz, J.J. Sokołowska, "Concrete-like polymer composites with fly ashes- comparative studies", Construction and Building Materials, vol. 38, 689-699, 2013

7. L. Czarnecki, A. Garbacz, J.J. Sokołowska "Fly ash polymer concretes", $2^{\text {nd }}$ International Conference on Sustainable Construction Materials and Technologies,127-138, Ancona, 2010

8. A. Garbacz, J. J. Sokołowska, "Concrete-like polymer composites with fly ashes- comparative studies", Construction and Building Materials, 38,689-699, 2013

9. I. Budniak, T. Płociński, K. Kurzydłowski, „Osad denny jako potencjalny napełniacz polimerów termoplastycznych", XXXIX Szkoła Inżynierii Materiałowej, Kraków- Krynica 2011, 389-394, 2011

10. P. Łukowski, J.J. Sokołowska, G. Adamczewski, B. Jaworska, „Waste perlite powder as the potential microfiller of polimer composites”, Mechanics and Materials, 193-200, Warsaw, 2013

11. B. Jaworska, J.J. Sokołowska, P. Łukowski, J. Jaworski, „Waste mineral powders as components of polymercement composites", Archives of Civil Engineering, 59, 199-210, 2015

12. N. H. A. Khalid, M. W. Hussin, J. Mirza, N. F. Ariffin, M. A. Ismail, H.S. Lee, A. Mohamed, R. P. Jaya, "Palm oil fuel ash as potential green micro-filler in polymer concrete", Construction and Building Materials, 102,950-960, 2016

13. M. Saribiyik, A. Piskin, A. Saribiyik, "The effects of waste glass powder usage on polymer concrete properties", Construction and Building Materials 47, 840-844, 2013 


\section{LIST OF FIGURES AND TABLES:}

Fig. 1. Verification of grain size distribution depending on the month in which the samples were collected

Rys. 1. Częstość względna rozmiaru cząstek w zależności od miesiąca pobrania próbek

Fig. 2. Verification of grain size distribution curves vs. mineral input composition. 1,2,3,4-mixture number

Rys. 2. Częstość względna rozmiaru cząstek w zależności od wkładu surowcowego. 1,2,3,4 - numer mieszanki

Fig. 3. Verification of grain size distribution curves of tested microfillers - relative frequency plot

Rys. 3. Częstość względna rozmiaru cząstek w zależności do rodzaju badanego mikrowypełniacza

Fig. 4. Verification of grain size distribution curves of tested microfillers - cumulative frequency plot

Rys. 4. Skumulowana częstość względna rozmiaru cząstek w zależności do rodzaju badanego mikrowypełniacza

Fig. 5. The mineral (A) and chemical (B) composition of the tested limestone powder

Rys. 5. Skład mineralny (A) i chemiczny (B) badanego pyłu wapiennego

Fig. 6. Microscopic photograph of waste limestone powder- grain shape

Rys. 6. Mikroskopowy obraz odpadowego pyłu wapiennego- kształt ziaren

Fig. 7. Microscopic picture of limestone powder waste: 1 - limestone grain , 2- aluminium silicate grain

Rys. 7. Mikroskopowy obraz odpadowego pyłu wapiennego: 1-cząstaka wapienna, 2-cząstka glinokrzemianowa.

Fig. 8. The chemical composition of selected grains: 1 - limestone grain , 2- aluminium silicate grain

Rys. 8. Skład chemiczny wybranych cząstek: : 1-cząstaka wapienna, 2-cząstka glinokrzemianowa

Fig. 9. Microscopic photograph of limestone powder waste - spatial grain arrangement

Rys. 9. Mikroskopowy obraz odpadowego pyłu wapiennego- przestrzenny obraz cząstek

Tab. 1. Physical characteristics of the tested limestone powder waste.

Tab. 1. Charakterystyka właściwości fizycznych badanego pyłu wapiennego

Tab. 2. Raw material input mixture proportions

Tab. 2. Składy mieszanek wkładu surowcowego

Tab. 3. Specific surface area, average diameter, mode diameter and content percentage under $120 \mu \mathrm{m}$ of tested microfillers.

Tab. 3. Powierzchnia właściwa, średnia średnica, moda, zawartość cząstek poniżej $120 \mu$ m badanych mikrowypełniaczy 


\section{CECHY CHEMICZNE I FIZYCZNE ODPADOWEGO PYLU WAPIENNEGO JAKO POTENCJALNEGO MIKROWYPELNIACZA KOMPOZYTÓW POLIMEROWYCH}

Słowa kluczowe: odpadowy pył wapienny, kompozyty polimerowe, mikrowypełniacz, analiza uziarnienia

\section{STRESZCZENIE:}

Wstępnym etapem produkcji mieszanek mineralno-asfaltowych (MMA) jest suszenie i odpylanie kruszywa grubego. Najczęściej stosowanymi typami kruszyw w produkcji MMA są wapienie i bazalty. W czasie procesu ich wstępnego przygotowania w suszarkach gromadzą się duże ilości odpadu w postaci pyłu mineralnego.

Uziarnienie pyłów pochodzących z filtrów suszarek zależy nie tylko od wkładu surowcowego, ale również od pory roku w której pyły zostały zgormadzone. Pyły pochodzące z odpylania kruszyw o podobnym składzie mineralnym wykazują podobne uziarnienie. Znaczące różnice mogą zostać zaobserwowane, gdy porównane zostaną pyły pochodzące z odmiennych wkładów surowcowych. Dalsze analizy były przeprowadzone dla pyłu wapiennego zgromadzonego w maju.

Można zauważyć, że pomimo iż charakter uziarnienia pyłu wapiennego jest odmienny od najczęściej stosowanej mikrokrzemionki to wartość najczęstsza jest zbliżona. Uziarnienie odpadowego pyłu wapiennego jest zbliżone do uziarnienia mikrokrzemionki, jednakże odznacza się zwiększoną zawartością grubszych ziaren (średnica 50-100 $\mu \mathrm{m}$ ). Warto jednak zauważyć iż prawie w całości odpad spełnia wymagania stawiane mikrowypełniaczom ( $98 \%$ ziaren ma średnicę poniżej $120 \mu \mathrm{m})$.

Badania składu mineralnego odpadowego pyłu mineralnego wykazały iż składa się on głównie z kalcytu. Jego zawartość wynosi ponad 85\%. W małych ilościach minerały z grupy węglanów są reprezentowane przez dolomit. Skład mineralny jest uzupełniony przez kwarc oraz minerały ilaste reprezentowane przez śladowe ilości illitu i kaolinitu. Petrograficznie, próbka odpadu jest mączką wapienną.

Kształt ziarna jest podobny do kształtu ziaren grubych kruszywa. Ziarna mączki wapiennej mają gładkie krawędzie, co skutkuje zmniejszeniem powierzchni właściwej. Może to być korzystne z uwagi na ilość spoiwa potrzebna do otoczenia ziaren. Zaobserwowany mikroskopowo kształt ziaren jest obiecujący z technologicznego punktu widzenia. Pod względem urabialności, konsystencji i małego zużycia spoiwa gładki kształt jest korzystny.

Skład chemiczny wskazuje na konieczność dalszej analizy kompatybilności odpadu wapiennego i spoiw. Większość używanych mikrowypełniaczy jest krzemionkowa, więc kompatybilność z mączką wapiennej jest nieznanym czynnikiem. Nie wyklucza to jednak wykorzystywania odpadowego pyłu wapiennego jako mikrowypełniacza w kompozytach polimerowych.

Warto rozważyć możliwość wykorzystania odpadowego pyłu wapiennego nawet jako częściowego zamiennika mikrokrzemionki. Sprawdzenia wymagałyby: urabialność, wytrzymałość i trwałość zmodyfikowanych kompozytów. Modyfikacja taka byłaby korzystna pod względem: ekonomicznym (redukcja kosztów materiałów) i względem ekologicznie (wykorzystanie odpadów). 